$1-1-16$ 鋂别診断用简易語音聘力検查法について

\title{
立 木孝，本間利美(岩手医大)
}

\section{回的}

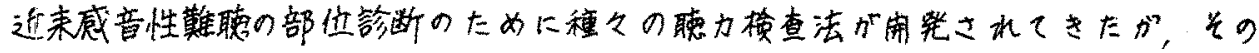

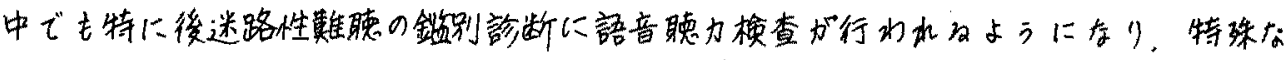

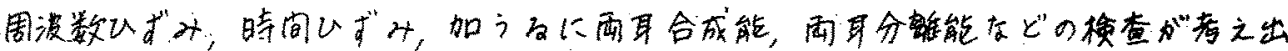

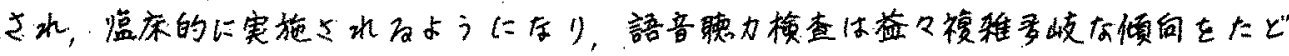
るようになった。このようなことで实際の煴床で語音㯖力模查の拖行にあたり多く

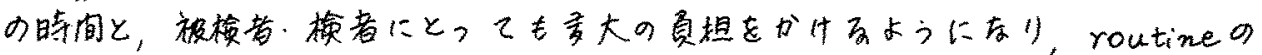
testとしては仲々実施困蚌なことのように思われる。

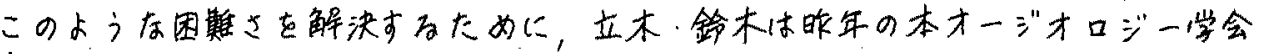

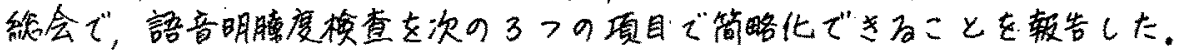

即与

(1) 語音闒值の绪定は行的ない。

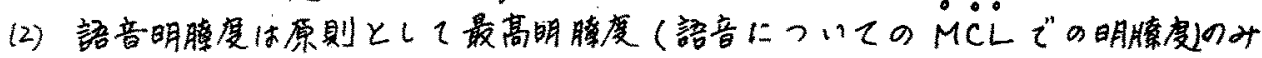
女测定す月。(Audiology Vol.10, No.3，P.170，参照)

(3) 語数は 20 語とし，さしあたりオ一ジオロジ一学会語音委員会で定められた 铻意单音铮表を用いる。

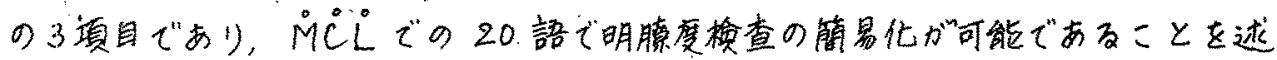
ベ，ミらに々の实施にあたり，基车的な明臊度の他に; 他の模查(ひずみ語音など) を施行しようとする隆は録音のトラォク数を增加するが，またはトラックの前半。

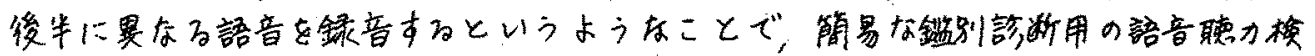
查ができる乙とを予告したが，吾々は今回次のよう应みつの装是を用いて，梌查棓

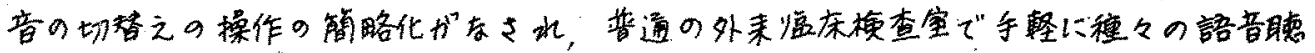
力楥查が行之るような方法を考之たので、こ一に教告する。

方法

(1)才小の装置は四1の如くで、ステレオ・テープレコーダーを4台並べ、一方 向2チャンネル・4トラック，合計16トラックのテープに種々の語音を银旦し， 中间の切替之スイっ4を介して24ャンネルオージオメーターに接繶し，スイッ4 を切替えることで，どのテープレコーダーがらも，任意のチャンネルをとり出すこ とガできんようにした。

(2) 并29装留は，どこででも入手できる市骐の4チャンネル・8トラっクの カ一、ステしオを利用し、こ扎をるチャンネルのオージオメータ一に接統し，雨耳 のレシーバーから聴取せしめた。(图2)

予めけつのステレオパックのエンドレス8トラっクの各トラックに同ーレベルで 回了9如专顺序で检查語音を録音しておき，ボタンを押すことで自由にラープの交 
182

换なしにチャンネルの逶択が可能である。（2チャンネル・4トラックのテープを 用いた場合でも，非常に簡单にだ゙パククをさし込むだサでテ一プの交换が可能で 西了。）

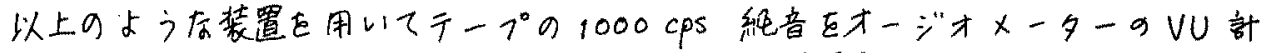

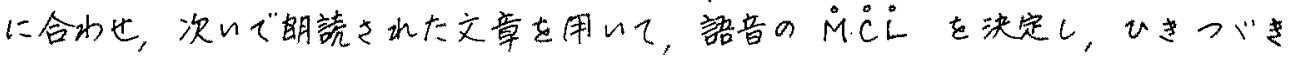
必要な語音模查朵”施行できる。

このような示法はすべて9模查語音を同ーレベルで同ーテープに録音しておいて， 任意に希望するチャンネルを简单な操作でとり出世るようにするなどの，鑑别讋断 用としての简易語音聴力㯖查の条件巨满足さ世及ようなものであると考え的れた。

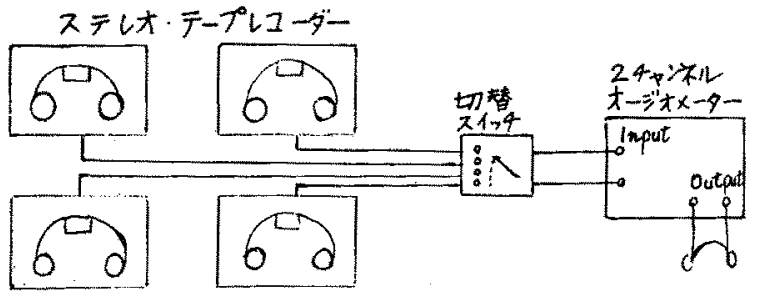

四 1

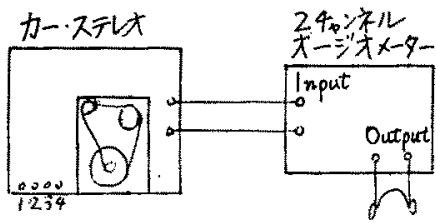

四 2

\begin{tabular}{|c|c|c|c|}
\hline \multicolumn{2}{|c|}{ チャンネルトラック } & 録音内容 & 目的 \\
\hline \multirow{2}{*}{ A } & 1 & 1000 cps 純音、文章朗誢 & $M C L$ \\
\hline & 2 & 20 語音 & 明暸度 \\
\hline \multirow{2}{*}{ B } & 3 & high pass & 周波数 \\
\hline & 4 & low pass & ひずみ \\
\hline \multirow{2}{*}{$c$} & 5 & 断镜語音 & 時 间 \\
\hline & 6 & " & ひずみ \\
\hline \multirow{2}{*}{ D } & 7 & 1 桁数字 & 両耳分 \\
\hline & 8 & " & 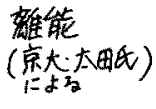 \\
\hline
\end{tabular}

图 3 